\title{
State Abortion Restrictions and the New Supreme Court: Women's Access to Reproductive Health Services
}

Rebecca Reingold

Georgetown University Law Center, rr951@law.georgetown.edu

Lawrence O. Gostin

Georgetown University Law Center, gostin@law.georgetown.edu

This paper can be downloaded free of charge from:

https://scholarship.law.georgetown.edu/facpub/2169

https://ssrn.com/abstract=3400964

The Journal of the American Medical Association.

This open-access article is brought to you by the Georgetown Law Library. Posted with permission of the author. Follow this and additional works at: https://scholarship.law.georgetown.edu/facpub

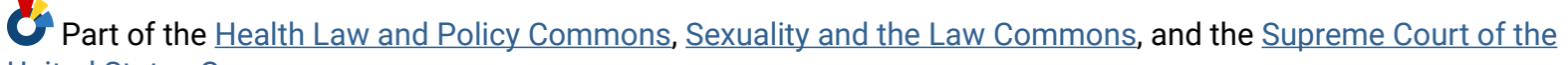
United States Commons 
Rebecca B. Reingold,

JD

O'Neill Institute for National and Global Health Law, Georgetown University, Washington, DC

\section{Lawrence O. Gostin,}

JD

O'Neill Institute for National and Global Health Law, Georgetown University، Washington, DC

\section{$+$}

Viewpoint

$+$

Supplemental content
Corresponding Author: Lawrence $\mathrm{O}$. Gostin, JD, O'Neill Institute for National and Global Health Law, Georgetown University Law Center, 600 New Jersey Ave NW, Washington, DC 20001 (gostin@law. georgetown.edu)
The US Supreme Court's landmark 1973 ruling in Roe $v$ Wade established a privacy right to choose abortion. In 1992, Planned Parenthood of Southeastern Pennsylvania $v$ Casey reaffirmed Roe with the Supreme Court calling reproductive decisions "the most intimate and personal choices a person may make...central to personal dignity." Casey allows abortion regulations, but states cannot impose an "undue burden," where the law's "purpose or effect" places a substantial obstacle in a woman's path in accessing an abortion previability.

State abortion restrictions-meaning laws that restrict whether, when, and under what circumstances a woman may obtain an abortion-increased in the aftermath of Roe and Casey, rising from an average of 14 (1983-2010) to 57 (2011-2015) restrictions per year. ${ }^{2}$ Today, states are enacting a new wave of restrictions, as the balance of the Supreme Court has shifted with the addition of more conservative members. Political speculation centers on whether the court will overturn Roe. Given Chief Justice Roberts' regard for judicial independence and nonpartisanship, it is unlikely the
Kentucky, Louisiana, Mississippi, Missouri, and Ohio banned abortion once a fetal heartbeat can be detected, around 6 weeks. Statutes often fail to grant exceptions for rape or incest, or for the woman's physical and mental health. Abortion prohibitions can carry harsh criminal penalties for physicians who perform the procedure, potentially subjecting them to up to 99 years imprisonment in Alabama. Penalties could also apply to women who access medication-induced abortions.

Beyond very restrictive laws, 20 states prohibit abortions at gestational stages closer to viability (18-22 weeks). Some laws would limit abortions to the extent the Supreme Court ultimately permits. ${ }^{4}$ In addition, various states have enacted bans designed to be "triggered" if Roe is overturned. ${ }^{4}$

Beyond direct abortion regulations, 9 states extend personhood to previable fetuses, defining "person" to include an "unborn child." State laws that regard fetuses as legal persons could support litigation challenging any attempt to abort a fetus. Of 38 state feticide laws, 29 apply to the earliest stages of pregnancy. ${ }^{5}$

On May 28, 2019, the Supreme Court upheld Indiana's law treating embryonic and fetal tissue like human remains. Adetailed summary of state abortion laws is shown in the eTable in the Supplement. prominent concerns, important values of equity and justice are at stake in the challenge to Roe $v$ Wade.

court would abandon well-settled precedent. Instead, the court could significantly limit the affordability of or access to abortions, reducing reproductive rights. The new legal environment would make it more difficult for women to make meaningful, science-based decisions in consultation with their physicians.

\section{The Politics of Roe}

Critics of Roe, right-to-life advocates, stress that states should regulate abortion democratically. Pro-choice advocates sometimes maintain Roe should have been grounded in gender equity. Justice Ruth Bader Ginsburg observed, "the Court ventured too far," failing to frame abortion restrictions as sex discrimination. ${ }^{3}$ The court is unlikely to review outright abortion bans but appears poised to incrementally uphold multiple restrictions.

Outright and Previability Bans

In 2019, 7 states enacted bans on abortion in all or most circumstances, clearly violating Roe and Casey. Alabama banned abortion at all stages of pregnancy. Georgia,

\section{Medical Procedures}

Lower courts struck down Oklahoma's ban on medication-induced abortion, which is approved by the US Food and Drug Administration for early nonsurgical pregnancy terminations. Yet 34 states require licensed physicians to perform all medication-induced abortions, despite scientific guidance that mid-level professionals can safely oversee the procedure. ${ }^{4}$ In 17 states, physicians may not use telemedicine to prescribe abortion medication remotely. ${ }^{4}$ State laws also ban later-term abortions. After the Supreme Court upheld the federal Partial-Birth Abortion Ban Act in 2007, 21 states maintain bans on intact dilation and extraction. ${ }^{4}$

Health Professionals and Institutions

States have also adopted laws that impose burdensome requirements for institutions that offer abortions, which exceed standards necessary to ensure patient safety. In 2016, the Supreme Court in Whole Woman's Health $v$ Hellerstedt struck down the requirement that institutions comply with ambulatory surgical standards. Yet onerous requirements remain in 17 states; 6 states require clinics to have transfer agreements with 
a local hospital. ${ }^{4}$ Whole Woman's Health similarly invalidated the requirement that health professionals have admitting privileges at a local hospital, but 3 states still maintain these rules. ${ }^{4}$

Nearly all states allow health professionals and institutions to refuse to perform abortions if they conscientiously object. Only 14 limit institutional exemptions to private and/or religious entities. ${ }^{4}$ The federal "conscience" rule also exempts covered entities from counseling or even referring patients to nonobjecting practitioners or centers, placing additional barriers on women's access. ${ }^{6}$

\section{Women's Decision-making}

State laws also affect the right of women to make their own abortion decisions. Thirty-seven states require parents to be involved in a minor's decision. ${ }^{4}$ State counseling requirements include mandated information about medical procedures, fetal development, and health risks. Twenty-seven states set a waiting period between counseling and abortion, ranging from 18 to 72 hours ${ }^{4} ; 26$ states require women to undergo an ultrasound, of which 3 require physicians to display and describe the image and 22 states require physicians to offer the opportunity to view the image. ${ }^{4}$ Some states ban abortions for specific reasons, namely the fetus' sex, race, or genetic anomaly. ${ }^{7}$

\section{Funding and Reimbursement}

Thirty-four states and the District of Columbia prohibit public funding for abortions, unless the woman's life is endangered or for rape or incest; 22 states prohibit insurance coverage for public employees. ${ }^{4}$ Additionally, 11 states prohibit all private insurance from covering abortions, and 26 prohibit abortion coverage in plans offered through Affordable Care Act exchanges. ${ }^{4}$

\section{The Future of Access to Reproductive Health Services} The Supreme Court is unlikely to overturn Roe but could uphold multiple abortion restrictions. In the future, women may experience multiple limitations on accessing services. Abortions are expensive, with lower-income women unable to pay out-of-pocket. Women in many counties, sometimes entire states, do not have coverage for abortion services through available health insurance plans. ${ }^{8}$ Burden- some rules will deter many health professionals and institutions from providing abortions. Board certifications or hospital privileges are not designed for patient safety, with no comparable medical procedure subjected to similar standards. Many women will have to travel long distances, wait longer, or incur higher costs. In 6 states, only 1 clinic offers abortion services; the courts have temporarily delayed Missouri from taking action to close the only abortion clinic in the state, pending ongoing litigation.

Women may delay or forgo services, feeling shame or stigma. Minors may not wish to notify their parents, while pregnant women may not want counseling or to view fetal images. Abortion laws, in effect, undermine the trust vital to the patient-physician relationship and may affect women's willingness to seek health care. Extreme abortion laws also impose harsh criminal penalties on health professionals, eroding physicians' exercise of clinical judgment. By defining fetuses as legal "persons," states would treat evidence-based abortions as serious crimes.

Restrictive laws also could jeopardize women's physical and mental health. Safer medication-induced abortions would be more difficult to access. Delaying abortions beyond the first trimester significantly increases health risks. Worse still, women might turn to clandestine abortions without expert medical oversight. Emotional trauma is just as real, as women are forced to choose between an unsafe abortion or carrying an unwanted pregnancy to term. Individually and in the aggregate, laws marginalize abortion from routine medical care and affect women's health and emotional well-being.

While women's dignity and safety are prominent concerns, important values of equity and justice are at stake in the challenge to Roe $v$ Wade. Irrespective of a state's legal environment, women with means will still be able to travel and pay for safe abortion services. The effects of additional restrictions will mostly involve already disadvantaged and underserved individuals, including women of color and women with lower incomes, less education, or rural residence. Current health, social, and economic inequities will be exacerbated. In the future, women's ability to access reproductive health services may hinge on where they live and whether they have resources.

\section{ARTICLE INFORMATION}

Published Online: June 5, 2019

doi:10.1001/jama.2019.8437

Conflict of Interest Disclosures: None reported.

Additional Contributions: The authors acknowledge Brenna Gautam, JD, Georgetown University Law Center, for her contributions to the eTable.

\section{REFERENCES}

1. Planned Parenthood of SE Pa v Casey, 505 US 833 (1992).

2. Guttmacher Institute. Last five years account for more than one-quarter of all abortion restrictions enacted since Roe. https://www.guttmacher.org/ article/2016/01/last-five-years-account-more-one- quarter-all-abortion-restrictions-enacted-roe. Published January 13, 2016. Accessed May 28, 2019.

3. Ginsburg RB. Some thoughts on autonomy and equality in relation to Roe $v$. Wade. North Carol Law Rev. 1985;63(2):375-386.

4. Guttmacher Institute. United States: abortion: state policies on abortion. https://www.guttmacher. org/united-states/abortion/state-policies-abortion. Accessed May 28, 2019.

5. National Conference on State Legislatures. State laws on fetal homicide and penalty-enhancement for crimes against pregnant women. http://www.ncsl.org/research/health/fetalhomicide-state-laws.aspx. Published May 1, 2018. Accessed May 28, 2019.
6. Gostin LO. The "conscience" rule: how will it affect patients' access to health services? Published online May 20. JAMA. 2019. doi:10.1001/ jama.2019.7656

7. Reingold RB, Gostin LO. Banning abortion in cases of Down syndrome: important lessons for advances in genetic diagnosis. JAMA. 2018;319(23): 2375-2376. doi:10.1001/jama.2018.6118

8. Salganicoff A, Sobel L, Ramaswamy A. Coverage for abortion services in Medicaid, marketplace plans and private plans. Henry J. Kaiser Family Foundation. https://www.kff.org/womens-healthpolicy/issue-brief/coverage-for-abortion-servicesin-medicaid-marketplace-plans-and-private-plans/. Published May 17, 2019. Accessed May 28, 2019. 